\title{
The Classical Swine Fever Problem in East Nusa Tenggara and its Controlling
}

\author{
Ester Muki Apriyani* \\ Faculty of Veterinary Medicine, Udayana University, Indonesia
}

Submission: May 15, 2018; Published: July 02, 2018

*Corresponding author: Ester Muki Apriyani, Faculty of Veterinary Medicine, Udayana University, Indonesia, Email: estermuki@gmail.com

Keywords: Classical Swinefever; Non-infectious diseases; Socio-economy; Sub acute; Pigs; Hog cholera; Livestock; Biosecurity; Vaccination; Socialization; Viruses; Reproductive; Potential; Feed

\section{Classical Swine Fever Problem in East Nusa Teng- gara}

One of the main causes of pig production and reproductive failure in Indonesia especially in East Nusa Tenggara is infectious and non-infectious diseases. One of the viral diseases that can attack pigs is Hog Cholera or Classical Swine Fever (CSF). Hog cholera or Classical Swine Fever (CSF), is an infectious viral disease caused by the hog cholera/ CSF virus. The CSF disease is still a problem in the livestock industry in East Nusa Tenggara and has the potential to have a negative impact on socio-economy, causing high animal mortality and causing public unrest. This disease can occur acutely, sub acute, and chronic accompanied by high morbidity and mortality $95-100 \%$.

Classical Swine Fever disease in East Nusa Tenggara was first reported in 1996 -97 on Timor Island and until 2017 most of the islands of East Nusa Tenggara province were already infected with CSF[1]. This indicates that the spread of CSF virus is very high and can also be associated with surveillance of inter-island livestock crossing. In 2011 the CSF outbreak occurred in Lembata district which killed about 696 pigs[2]. The latest report in mid2017, the outbreak of CSF attacked pigs in East Nusa Tenggara, especially on the Flores island. The number of livestock that died at the outbreak reaches about 10,000 pigs with an estimated economic loss of Rp 25 billion[3]. The occurrence of CSF outbreaks can be influenced by the sanitation factor of the cage and also the farmer's awareness of the importance of vaccination. Considering traditional maintenance practices can create poor farming biosecurity including the cleanliness of the animal dwelling environment and the livestock traffic arrangements. In addition, poor sanitationcan increase the presence of mechanical vectors of CSF viruses that are insects (flies and mosquitoes) [4]as well as the remaining feed in the form of animal origin contaminated with CSF virus can also be a source of transmission. Vaccination factors also take an important part in the spread of CSF disease in East Nusa Tenggara[5]. In addition to the failure factor of vaccination, awareness of farmers to vaccinate the livestock is still very minimal. The low public awareness of the importance of vaccination becomes an important task for the government to become more active in socializing and recording the development of CSF and vaccination diseases, so that the incidence of CSF cases can be controlled in the future.

\section{The Impacts of Classical Swine Fever Disease and its Controlling}

Although CSF is not a food borne disease, but the morbidity and mortality rate of $100 \%$ result in extensive social impacts such as loss of confidence or public interest to consume pig products[6]. Therefore, the material of origin of pigs need attention and also more control so that the material of animal origin of pigs really safe, healthy and intact. In addition, the economic losses felt by farmers are also so high that it needs to be done to prevent the outbreak of CSF can be minimized. The CSF virus can survive for weeks or even months in moist environments, e.g., ham, sausages, fresh pork and excretions of infected pigs it. Contaminated meat and meat products are dangerous sources for the spread of CSF or the fresh introduction of the infection into CSF-free regions, respectively[7]. Important things to do in controlling and eradicating CSF disease are:

i. Vaccination and treatment. CSF vaccine is an effective way to prevent CSF disease. There is noeffective cure for hog cholera. Administration of antibiotics is only to prevent 
secondary infection of bacteria. While the giving of vitamin intended to boost immunity.

ii. Implementing strict biosecurity. This can be done by monitoring the clinical symptoms of the disease, regulating the disposal of livestock waste, disinfecting equipment and cages regularly, reducing the food that comes from the rest of the restaurant or household containing pork carcasses.

iii. Handling in emergency outbreaks. In new cases rapidly reported mass destruction can be done to eliminate the source of rapid transmission of hog cholera virus. Conditional depopulation or deduction is done when the disease has spread and is not rapidly handled. While the destruction of equipment and contaminated material (disposal) is also necessary given the virus remains infective for a long time in agricultural land, especially if the area contains many pig farms. If no cases appear formonths then the cage that was previously infected with CSF can be refilled.

iv. Restructuring farms. The location of the farm should be far from the settlement to avoid the occurrence of transmission of CSF virus originating from household waste to pig farms or vice versa prevents so as not to pollute the settlement environment. Livestock management such as livestock breeding, feeding, sanitation and animal health should be well regulated for livestock quality improvement.

v. Supervision and control of live pig traffic and its products. Given that the province of East Nusa Tenggara is divided into many islands, livestock traffic and its products need to be closely monitored to prevent the spread of disease from infected areas to free areas.

vi. Communication, information and education is done through socialization to build public trust especially farmers, obtain correct information,transparency, and arouse public participation in handling hog cholera.

vii. Routine surveillance. Recording the data of CSF disease incidence is very important to know the history of the spread and development of disease prevention in order to really be controlled in the future.

Rapid and appropriate eradication of Classical Swine Fever/ Hog Cholera disease can only be done if the incident is reported quickly to the authorized officer so that the cooperation is needed between the East Nusa Tenggara government and the public in order to maximize the control of CSF disease.

\section{References}

1. Jenny-Ann (2011) Seminar on Hog Cholera in Nusa Tenggara Timur (NTT).

2. Tenaya IWM, Diarmita IK (2013) Situation overview and Surveillance results of Hog Cholera in Area Responsibility of Balai Besar Veteriner Denpasar in 2009-2012. Buletin Veteriner, 15: 82.

3. Bali Animal Husbandry Department (2010) The Strategic Infectious Diseases Guideline. From proceedings of Health Maintenance Activity and Prevention of Livestock Infectious Diseases.

4. Hayong E (2018) 10,000 Pigs in Flores Dead Attacked by Hog Cholera, Animal Husbandry Department of East Nusa Tenggara Do This. Pos Kupang, Indonesia.

5. Animal Husbandry Department Launches Hog Cholera Eradication Strategy. Timor Express, Indonesia.

6. Entomological Society of Indonesia. (2010) Empowerment of Insect Diversity for Increasing Community Welfare. proceedings of National Seminar V.

7. Volker Moennig (2015) The control of classical swine fever in wild boar. Frontiers in Microbiol 6: 1211.

\section{Your next submission with Juniper Publishers} will reach you the below assets

- Quality Editorial service

- Swift Peer Review

- Reprints availability

- E-prints Service

- Manuscript Podcast for convenient understanding

- Global attainment for your research

- Manuscript accessibility in different formats

( Pdf, E-pub, Full Text, Audio)

- Unceasing customer service

Track the below URL for one-step submission https://juniperpublishers.com/online-submission.php 